\title{
Edukasi Teknologi Produksi dan Aplikasi Baterai Lithium Ion pada Kendaraan Listrik di SMK Muhammadiyah 6 Karanganyar
}

\author{
Endah R Dyartanti ${ }^{1}$, Tika Paramitha ${ }^{1}$, Hendri Widiyandari ${ }^{2}$, Arif Jumari ${ }^{1}$, Adrian Nur ${ }^{1}$, Anatta W Budiman ${ }^{1}$
} dan Agus Purwanto ${ }^{1}$

1 Program Studi Teknik Kimia Fakultas Teknik, Universitas Sebelas Maret

2 Program Studi Fisika Fakultas MIPA, Universitas Sebelas Maret

E-mail: a endah_rd@staff.uns.ac.id(Corresponding author)

\begin{abstract}
.
Electric vehicles are vehicles that are driven by electric motors from the battery as energy sources. The advantages of electric vehicles related to their high energy conversion include reducing fuel oil consumption and reducing exhaust emissions. The advanced materials and energy storage research group is currently developing researches on battery production and its applications. This educational activity is a part of the Research Group Service Grant (HGR-UNS) which aims to disseminate the results of research on batteries and their application to electric vehicles as a form of advanced technology transfer for Vocational High School (SMK) students. SMK students must be provided with knowledge about lithium-ion batteries (LIB) and electric vehicles so that they can improve their competence and increase their competitiveness in the job market. SMK Muhammadiyah 6 Karanganyar offers several programs so that this educational activity will greatly support students' learning activities. This education activity is also the continuation of interns' activities at the Center for Excellence in Higher Education Science and Technology for Electrical Energy Storage Technology. With this educational activity's implementation, we wish to increase students' knowledge about battery technology and its applications.
\end{abstract}

Keywords: education; Lithium-Ion Battery; Electric Vehicle

EQUILIBRIUM Volume 4 No.2 December 2020

Online at http:// equilibrium.ft.uns.ac.id 


\section{Pendahuluan}

Indonesia adalah salah satu negara berkembang di dunia dengan pertumbuhan penduduk yang relatif tinggi. Pertambahan jumlah penduduk mengakibatkan berbagai dampak terhadap aspek kehidupan manusia, seperti peningkatan populasi kendaraan bermotor [1]. Berdasarkan data dari Badan Pusat Statistik, dalam sepuluh tahun terakhir jumlah kendaraan bermotor seperti mobil penumpang, mobil barang, dan sepeda motor mengalami peningkatan dari 61.685.063 pada tahun 2008 menjadi 146.858.759 pada tahun 2018. Hampir semua kendaraan bermotor tersebut menggunakan bahan bakar minyak (BBM) sebagai sumber energinya [2]. Penggunaan BBM menimbulkan tantangan bagi negara Indonesia seperti defisit produksi minyak bumi dan timbulnya polusi udara akibat gas buang kendaraan.

Kendaraan listrik adalah salah satu pilihan solusi untuk mengurangi ketergantungan penggunaan BBM [3]. Kendaraan listrik merupakan kendaraan yang digerakkan dengan motor listrik dan mendapat sumber daya listrik dari baterai. Saat ini, baterai yang banyak digunakan pada kendaraan listrik yaitu baterai lithium ion dikarenakan kepadatan energi yang tinggi, kepadatan daya yang tinggi, siklus, dan keamanan yang baik [4]. Keuntungan kendaraan listrik dibandingkan dengan kendaraan konvesional antara lain tidak bising, efisiensi konversi energi yang tinggi, mengurangi pemakaian bahan bakar minyak sehingga secara langsung mengurangi gas buang ke atmosfir, serta emisi gas [5].

Pada tahun 2019, Presiden telah mengesahkan Peraturan Presiden Republik Indonesia Nomor 55 Tahun 2019 tentang percepatan program kendaraan bermotor listrik berbasis baterai (battery electric vehicle) untuk transportasi jalan. Sejalan dengan program pemerintah tersebut dan terus berkembangnya teknologi tentang kendaraan listrik, Sekolah Menengah Kejuruan (SMK) dengan program keahlian teknik kendaraan ringan dan teknik elektronika hendaknya menyiapkan lulusan yang mempunyai pemahaman mengenai kendaraan listrik berbasis baterai ion lithium (BIL). Pengetahuan tentang BIL juga sangat penting karena baterai ini merupakan salah satu kunci energi terbarukan. Dengan begitu, para siswa lulusan SMK diharapkan dapat mempunyai pengetahuan sesuai dengan perkembangan teknologi saat ini dan memiliki daya saing yang tinggi.

Permasalahan yang muncul adalah sebagian besar SMK pada program keahlian teknik kendaraan ringan terfokus mempelajari kendaraan konvensional dengan menggunakan bahan bakar minyak. Pada proses pembelajaran di SMK Muhammadiyah 6 Karanganyar, siswa lebih banyak menggunakan kendaraan yang ada di pasaran seperti Toyota, Honda, Suzuki, Daihatsu. Sementara, kendaraan listrik tidak digunakan sebagai bahan praktik. Selain itu, lulusan SMK program keahlian teknik elektronika perlu memiliki pemahaman mengenai komponen BIL dan sistem kelistrikan pada kendaraan listrik.

Menindaklanjuti hal tersebut, pada pengabdian ini akan dilakukan edukasi di SMK Muhammadiyah 6 Karanganyar mengenai baterai lithium ion dan aplikasinya pada kendaraan listrik, yang merupakan hasil riset di Universitas Sebelas Maret. Sehingga, kegiatan ini dapat memberikan pemahaman kepada siswa mengenai mengenai konsep dasar kendaraan listrik dan menumbuhkan inovasi pada siswa untuk mengembangkan kendaraan listrik.

\section{Analisis Permasalahan Mitra}

Persoalan yang muncul adalah SMK Muhammadiyah 6 Karanganyar program keahlian teknik kendaraan ringan fokus untuk mempelajari kendaraan konvensional dengan menggunakan bahan bakar minyak. Pada proses pembelajaran di SMK Muhammadiyah 6 Karanganyar, siswa lebih banyak menggunakan kendaraan konvensional yang menggunakan BBM yang terdapat di pasaran. Sementara, kendaraan listrik tidak digunakan sebagai bahan praktik. Selain itu, masih sedikit siswa yang memiliki pengetahuan mengenai baterai lithium ion. $\mathrm{Hal}$ ini disebabkan penelitian dan pengembangan baterai lithium ion masih tergolong baru. Pemahaman mengenai kendaraan listrik juga diperlukan oleh siswa dengan program keahlian teknik elektronika, khususnya mengenai komponen BIL dan sistem kelistrikan kendaraan listrik. Peranan perguruan tinggi melalui darma ketiga yaitu pengabdian masyarakat sangat dibutuhkan oleh SMK Muhammadiyah 6 Karanganyar agar SMK Muhammadiyah 6 Karanganyar dapat terus menerus menyesuaikan dengan perkembangan teknologi terutama teknologi kendaraan listrik dan mencetak lulusan sesuai dengan kebutuhan industri 


\section{Solusi Terhadap Permasalahan Mitra}

Kegiatan pengabdian ini bertujuan untuk memberikan penyelesaian permasalahan yang dihadap yaitu terwujudnya pemahaman siswa mengenai dampak positif kendaraan listrik, terwujudnya pemahaman siswa mengenai BIL dan meningkatkan pengetahuan siswa mengenai aplikasi baterai pada kendaraan listrik yang sederhana, seperti sepeda listrik dan motor listrik. Kegiatan ini juga bertujuan untuk mengembangkan inovasi siswa dan guru SMK Muhammadiyah 6 Karanganyar mengenai kendaraan listrik, meningkatkan daya saing lulusan SMK Muhammadiyah 6 Karanganyar sehingga mampu berkompetisi dengan lulusan sekolah lainnya khususnya mengenai kendaraan listrik dan BIL dan kerjasama secara kontinyu mengenai pengembangan kendaraan listrik.

\section{Metode Pelaksanaan Pengabdian \\ 4.1. Inventarisasi Permasalahan}

Kendaraan listrik adalah salah satu pilihan solusi dari ketergantungan penggunaan bahan bakar minyak. Saat ini, sekolah menengah kejuruan khususnya program keahlian teknik kendaraan ringan dan otomotif dan teknik elektronika hendaknya menyiapkan lulusan dengan pemahaman tentang kendaraan listrik dan baterai lithium ion. Tetapi untuk mencapai hal tersebut sangat sulit, hal ini disebabkan oleh masalah-masalah sebagai berikut:

a. Proses pembelajaran hanya terfokus pada mempelajari kendaraan konvensional dengan menggunakan bahan bakar minyak.

b. Kurangnya inisiatif siswa untuk mengikuti perkembangan teknologi, khususnya mengenai kendaraan listrik.

c. Masih kurangnya pengetahuan guru mengenai kendaraan listrik dan Aplikasi BIL karena penelitian dan pengembangan mengenai kendaraan listrik dan baterai masih tergolong baru.

\subsection{Metode Pendekatan Pemecahan Permasalahan}

Untuk memecahkan permasalahan yang telah terinventarisir dicarikan metode dan solusi pemecahannya, langkah-langkah yang ditempuh adalah sebagai berikut :

a. Memberikan pengetahuan mengenai dampak positif penggunaan kendaraan listrik untuk menumbuhkan inovasi pengembangan kendaraan listrik

b. Mengenalkan produk riset mengenai komponen kendaraan listrik berupa BIL, sehingga dapat menjalin kerjasama dalam pengembangan kendaraan listrik.

c. Memberikan pengetahuan mengenai kendaraan listrik yang telah dihasilkan, seperti sepeda listrik dan motor listrik.

\subsection{Partisipasi Mitra dalam Pemecahan Permasalahan}

Mitra yang terlibat dalam pengabdian ini adalah SMK Muhammadiyah 6 Karanganyar khususnya program keahlian teknik kendaraan ringan dan teknik elektronika. Selama ini, proses pembelajaran pada teknik kendaraan ringan terfokus pada mempelajari kendaraan konvensional dengan menggunakan bahan bakar minyak. Padahal, dengan berkembangnya teknologi dibutuhkan lulusan sekolah menengah kejuruan yang memiliki pemahaman mengenai kendaraan listrik. Selain itu, siswa program keahlian teknik elektronika perlu memahami sistem kelistrikan kendaraan listrik. Kendaraan listrik merupakan salah satu pilihan solusi dalam mengurangi ketergantungan penggunaan bahan bakar minyak. Pengabdian masyarakat ini akan menjadi sarana dalam peningkatan kapasitas lulusan SMK Muhammadiyah 6 Karanganyar. Maka kunci untuk mewujudkan keberhasilan pengabdian ini adalah adanya dukungan seluruh civitas akademika SMK Muhammadiyah 6 Karanganyar, khususnya guru dan siswa program keahlian teknik kendaraan ringan dan teknik elektronika. Oleh karena itu, partisipasi yang diharapkan dari siswa dan guru: sikap dan keinginan untuk terus maju dan berkembang dari siswa dan guru, sikap untuk mau belajar mengenai hal baru dari siswa dan guru dan sikap untuk meningkatkan daya saing dengan kemampuan dan pemahaman yang lebih baik.

Edukasi Teknologi Produksi dan Aplikasi Baterai Lithium Ion pada Kendaraan Listrik di SMK 


\subsection{Evaluasi Pelaksanaan Kegiatan}

Untuk menilai keberhasilan kegiatan pengabdian ini maka kegiatan ini dilakukan evaluasi keberhasilannya melalui metode penilaian pemahaman siswa mengenai dampak positif kendaraan listrik, pemahaman siswa mengenai baterai lithium ion dan pemahaman siswa mengenai kendaraan listrik

\section{Hasil dan Pembahasan}

Kegiatan edukasi tentang Teknologi Produksi dan Aplikasi Baterai Ion Lithium pada Kendaraan Listrik dilakukan di SMK Muhammadiyah 6 Karanganyar. Kegiatan yang dilaksanakan pada hari kamis, 27 Agustus 2020 ini diawali dengan pembukaan oleh Ibu Kepala Sekolah dilanjutkan pengantar oleh ketua kegiatan pengabdian dilanjutkan dengan edukasi oleh nara sumber seperti terlihat pada gambar 1.
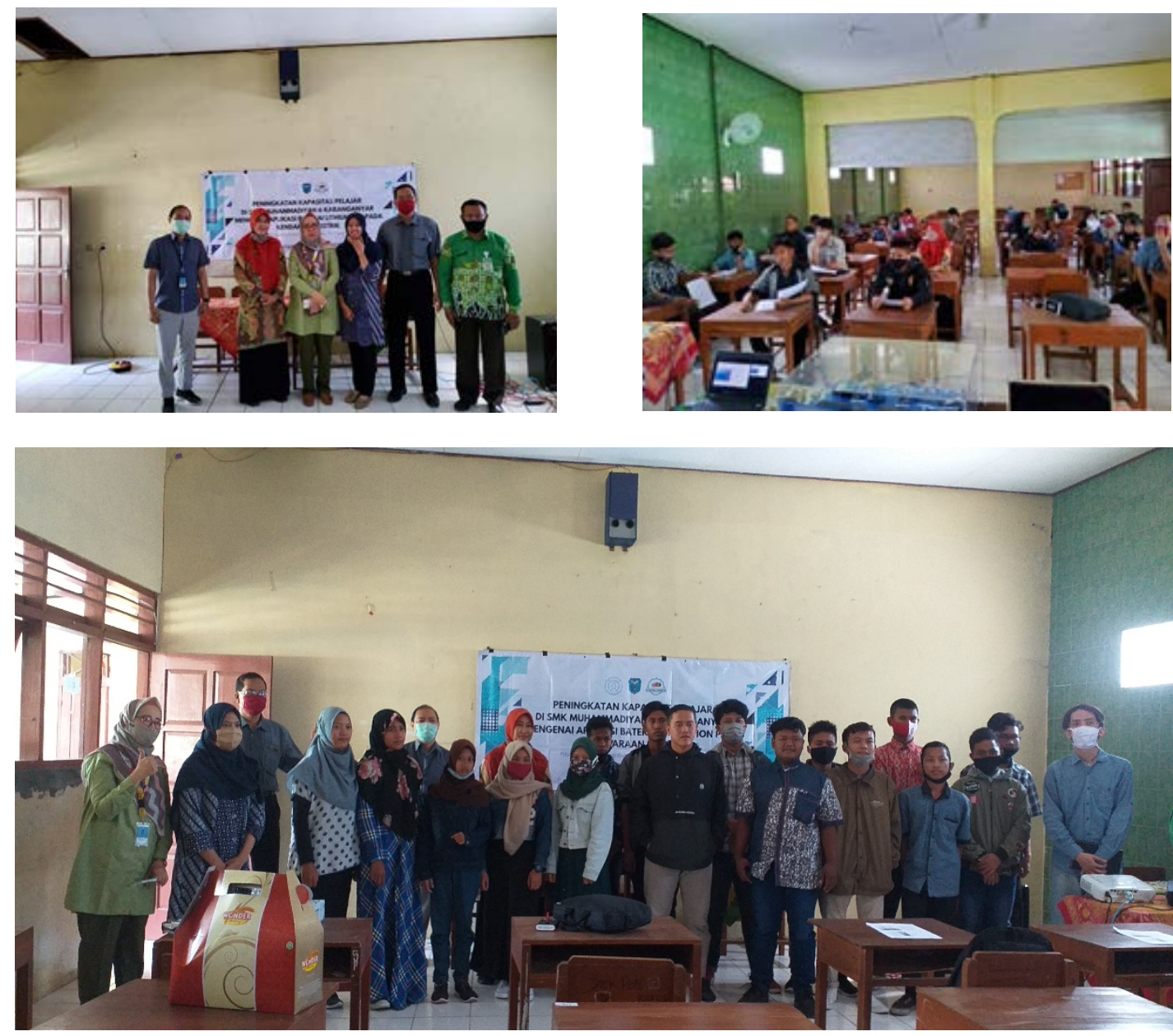

Gambar 1. Foto Kegiatan Kegiatan Pengisian Kuesioner oleh Mitra Sasaran

Edukasi diawali dengan tanya jawab sebagai bentuk penjajagan untuk mengetahui tingkat pengetahuan awal mitra mengenai baterai dan cara pemakaiannya yang benar untuk menghindarkan dari bahaya yang ditimbulkan karena kesalahan pengoperasian, serta pengetahuan siswa mengenai aplikasi penggunaan baterai.

Kegiatan pemberian edukasi tentang pembuatan baterai dan aplikasinya pada kendaraan listrik dilakukan menggunakan media presentasi untuk membantu mitra memahami materi. Materi edukasi menitikberatkan pada proses produksi baterai dan aplikasinya pada kendaraan listrik. Edukasi yang diberikan yaitu mengenai komponen baterai, cara pembuatan sel baterai, aplikasi baterai untuk kendaraan listrik, cara merakit sepeda listrik dan perangkaian sel baterai, serta edukasi bagaimana menggunakan dan mengoperasikan baterai isi ulang yang baik dan benar untuk mencegah adanya bahaya yg timbul karena kesalahan prosedur.

Kegiatan edukasi dilanjutkan dengan sesi tanya jawab oleh para siswa sebagai mitra. Siswa cukup aktif dan memberikan respon yang baik terlihat dari beberapa pertanyaan yang diajukan kepada nara sumber. 
Setelah sesi tanya jawab, para siswa diberikan kuisioner kembali sebagai postes untuk mengetahui tingkat pengetahuan setelah diberikan edukasi. Setelah kegiatan edukasi berakhir, pemateri memberikan kesempatan mitra untuk konsultasi melalui media sosial dan email.

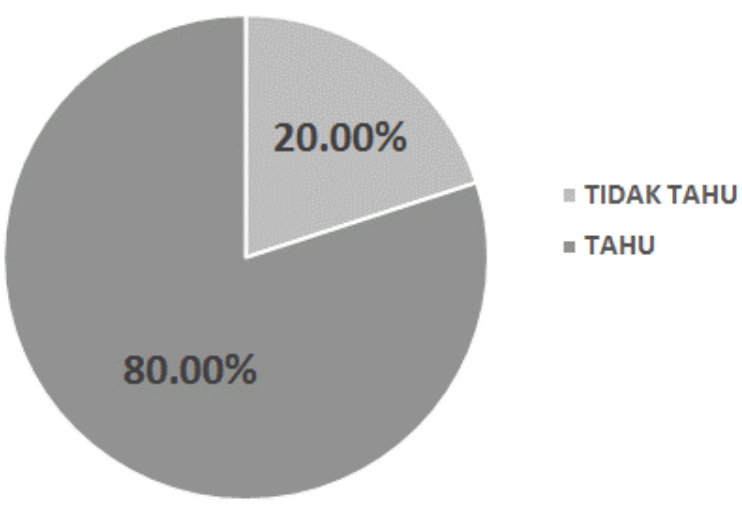

Gambar 2. Diagram Pengetahuan Mitra tentang Pengoperasian dan Bahaya Penggunaan Baterai Isi Ulang

Dari hasil jawaban mitra yang diperoleh dari pretes kemudian dibandingkan dengan hasil pos tes. Berdasarkan hal tersebut, mitra mengalami peningkatan pengetahuan tentang pengoperasian dan bahaya penggunaan baterai isi ulang (handphone dan laptop) dari kondisi awal hanya $10 \%$ siswa yang paham meningkat menjadi $80 \%$. Beberapa hal yang menjadi indicator adalah tidak mengisi daya listrik di tempat yang berbahaya dan waktu pengisian serta tanda-tanda berbahaya yang harus diperhatikan

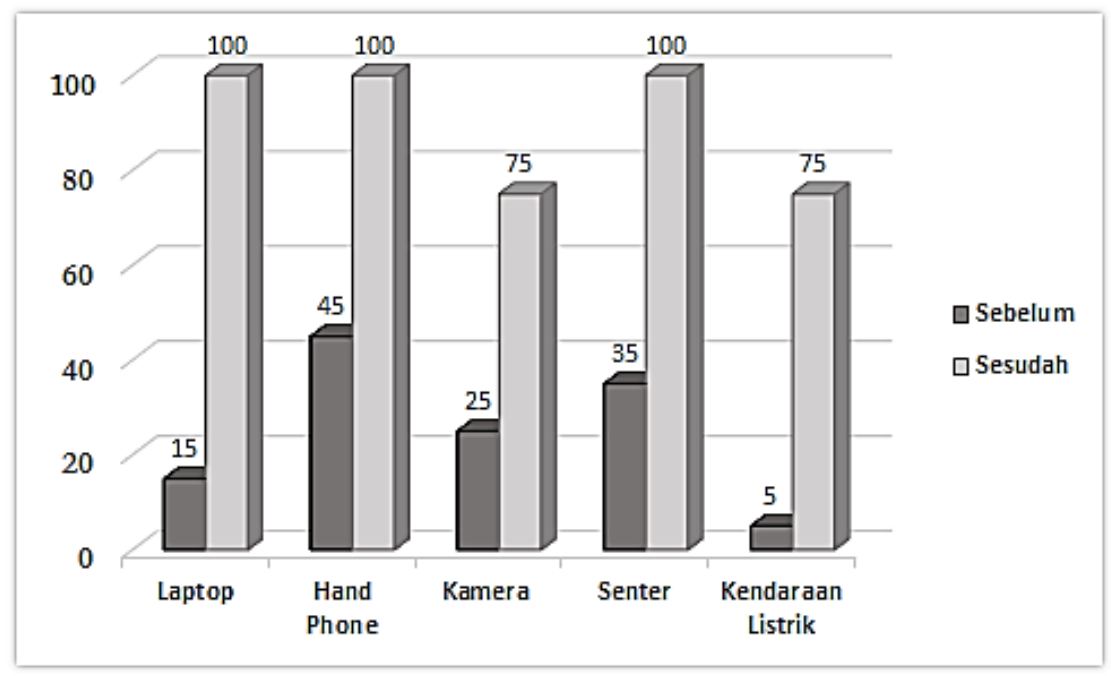

Gambar 3. Diagram Pengetahuan Mitra tentang Aplikasi Penggunaan Baterai

Pengetahuan siswa tentang aplikasi penggunaan baterai pada kehidupan sehari-hari meningkat antara $55 \%-85 \%$ (gambar 3). Siswa menjadi lebih paham bagaimana fungsi dan cara kerja baterai di setiap alat yang digunakan. Khusus untuk kendaraan listrik siswa menaruh perhatian yang sangat besar karena menjadi suatu hal baru dan menarik. Para siswa banyak bertanya tentang cara merakit modul baterai untuk sepeda listrik dan motor listrik

\section{Ucapan Terimakasih}

Penulis mengucapkan terimakasih kepada Universitas Sebelas Maret yang telah mendanai kegiatan Edukasi sebagai kegiatan Pengabdian Kepada Masyarakat ini dengan Hibah Grup Riset - Dana PNBP UNS Tahun

Edukasi Teknologi Produksi dan Aplikasi Baterai Lithium Ion pada Kendaraan Listrik di SMK 
2020 dengan No . kontrak : 453/UN.27.21/PN 2020. Terimaksih juga disampaikan kepada siswa dan guru SMK Muhammadiyah 6 Karanganyar dan Mahasiswa yang telah membantu suksesnya acara ini.

\section{Kesimpulan dan Saran}

\subsection{Kesimpulan}

1. Peningkatan pengetahuan siswa mengenai pengoperasian dan bahaya penggunaan baterai yang tidak sesuai dengan prosedur seperti cara mengisi daya yang aman dan sesuai prosedur. cara penyimpanan baterai dan cara pengoperasian yang aman dan baik

2. Peningkatan pengetahuan siswa terkait dengan aplikasi baterai untuk alat-alat dalam kehidupan sehari-hari untuk menambah pengetahuan dan teknologi tentang aplikasi baterai

\subsection{Saran}

Perlu adanya kegiatan kerjasama lebih lanjut sehingga bias dilakukan kegiatan praktek yang melibatkan siswa SMK secara langsung dalam produksi batera

\section{DAFTAR PUSTAKA}

[1] T. P. F. Sompie, S. L. Sengkey, and S. Pangemanan, "Pengukuran CO pada Ruas Jalan untuk Mereduksi Polusi Udara yang Ditimbulkan oleh Kendaraan Bermotor," pp. 227-232, 2013.

[2] A. Sugiyono, "Pemanfaatan Biofuel dalam Menunjang Penyediaan Energi Nasional Jangka Panjang," no. December 2005, pp. 78-86, 2015.

[3] M. H. dan H. L. Muhammad Firman, "Rancang bangun sepeda listrik dengan tenaga surya sebagai kendaraan alternatif dan ramah lingkungan untuk masyarakat," jurnail sains dan Teknol. Univ. Islam Kalimantan Muhammad Arsyad Al Banjary Banjarmasin, vol. 1, no. 2, pp. 102-107, 2016.

[4] S. Chen et al., "Ordered mesoporous carbon / sulfur nanocomposite of high performances as cathode for lithium - sulfur battery," Electrochim. Acta, vol. 56, no. 26, pp. 9549-9555, 2011.

[5] I. W. Sukerayasa, "Tinjauan Perkembangan Kendaraan Listrik Dunia Hingga Sekarang," Maj. Ilm. Teknol. ELektro, vol. 8, 2009. 